\title{
ビーチロックとその類似地形
}

\section{米谷静 二*}

摘要 1. 主として沖永良部島の大津勘・白浜のビーチロックについて記載した. ここには，筆者のこれ まで調査したビーチロックに関する各種の形態が分布し，問題点が集約的に表現されていると考えられるか らである. 形態記載の便宜上，各部の名称について仮提案をした．2. ビーチロックの地形学上の意義は， a 。汀線指示者 b. 気候指示者の 2 項に尽きるが，いずれにしても現在“どこに”生成中であるかが重大 な問題となる. 大津勘のビーチロックについて，とくに台風直後の地下水面との関係を調査することができ た. 約 $1 \mathrm{~m}$ の海岸砂の下に出現した白色新鮮なビーチロックを現在生成中のものと断定することができれば, これはこの問題について一つの鍵を提供するものであ万う。しかし実証がはなはだ困難である．3. ビーチ ロックの類似地形を, ビーチロックの成因追究の側面手段として調查した. これらの分布が海岸地帯に限ら れていることは, 石灰化作用について海水中の何らかの成分が関与していることを暗示するものと思われる.

\section{I.まえがき}

この報告は ${ }^{1}$ 先報以後に判明した事実について述 ベる，それらを要約すると次のようである。

1. 分布一先報にて種子島一竹島を北限としたが その後, 橘2》によって長崎県五島のものが報告され， 北限はいちじるしく北上した。 そのほか各地で多数 のビーチロックが発見され，形態的にもかなり多種 類のものが存在することがわかった。また類ビーチ ロック地形と総称すべき地形も少くない。

2. 存在位置 ビーチロックは一般に高温地域の ビーチに分有し，背後に砂丘をもつことが多い，砂 丘を切る間歇性河流の河口付近にビーチロックが発 達することがもっとも多いが，これは地下水説にと って有力な事実である。しかしこのような条件の砂 浜があってもかならずビーチロックが存在するとは 限らない. 五島, 甑などの分布限界線付近のビー チロックについては，いずれも背後にラグーンをも つことが知られているが，これも絶対的な必要条件
ではない，鹿児島湾東岸のものについてはラグーン は存在しない。

3. 海水位との関係 典型的なビーチロックは潮 間帯に存在する。しかし精査するとそのほか上部に 偏するものと下部に偏するものがある。これらがビ 一チロック生成時の海況によるのか，生成後の地盤 の相対的な運動を示すのかは未決定である.

4. 台風との関係 たまたま 1965 年 8 月，沖永 良部島調査中，台風 15 号 (Jean) に遭遇し，台風前 後の海浜の変化を観察することができた。後に詳記 するが，台風直後の砂の移動によって地下水面に平 行するビーチロックの存在を確認した。

5. 侵蝕形態 ふつうの溶食, 波食のほか, 層理 構造にもとずく剝離現象がかなり重要であることが 判明した.しかしこの反対に大きな板状の転石がビ 一チロックの上に乗り, それがその後, 膠結作用を うけて一見ひと続きのビーチロックのようになって いる実例も多い。

* 鹿児島大学 Kagoshima Univ..

1）米谷 静二：奄美大島本島北部におけるビーチロックの予察的研究，地理評，36.9

S. Yonetani : The Beach Rock on the South-West Islands of Japan (2)，鹿児島大学文理学部史学科 報告 13,

2）稠行一：五島列島奈留島の繩文土器を含むビーチロック，科学 Jun., 1964

同：五島の beachrock について (その 1), 長崎大学教養部紀要自然科学, 4 


\section{II. ビーチロックの典型的形態と各部分の名}

称 (仮案).

典型的なビーチロックが海に緩斜する数枚の地層 より成り，微小なケスタ状を示すことは先報のとお りである．形態記載の便宜上，第 1 図のように各部 分に仮称をつけた。

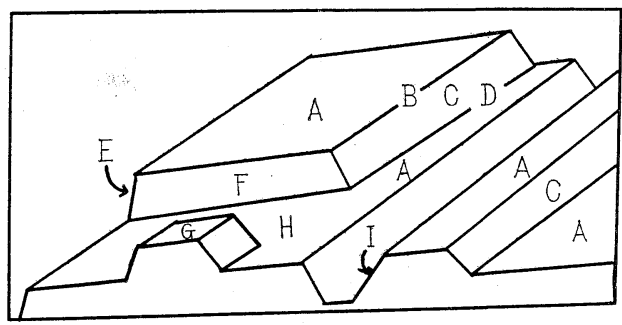

第 1 図 ビーチロック各部の名称仮案

A背面 B稜線 C崖面 D滗線 E 前崖

F側面 G残り面 H剝離面 I 逆崖

原則的には背面と崖面とが交互し，稜線は汀線に 平行な直線となる。海への末端は海底堆積物中に埋 まることもあるが，高さ $50 \sim 100 \mathrm{~cm}$ の前崖を形成 することが多い．前崖は急斜し，ときにはオーバー ハングする．側面や逆崖面はビーチロックの原地形 ではなく，亀裂をもとにしてしだいに発達する侵創 地形であるが，砂中で生成中のものにも見られるこ とがある。また背面の一部が剝離して残り面を残す ことがあるが，前述のように板状の転石が付着して 残り面に類似した形態を示すことも珍しくない.

\section{以下若干の実例について述べう。}

\section{1.（実例 1 ） 大津勘，沖永良部島}

大津勘・徳時両部落間の谷（佐久田俣川）の河口 部に長さ $1 \mathrm{~km}$ ， $100 \mathrm{~m}$ ほどの砂浜があり，各種の ビーチロックが出現するので，やや詳細に記述した い. 第 2 図は 25,000 分の 1 地形図, 沖永良部島西 部を拡大した基罒に書き入れた現地の見取図である.

a. 二枚貝，巻貝の殼を多量に含む緻密なさんご 石灰岩より成る隆起さんご礁の岬である，下部にべ ンチが付着している。ベンチとビーチロックの差異
については $\mathrm{i}$ 参照.

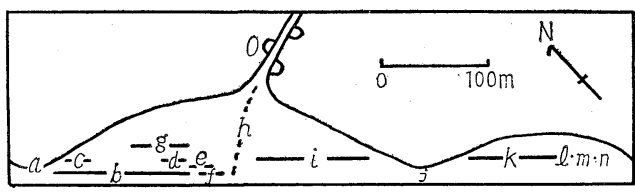

第 2 図大津勘の浜の見取図 $\mathrm{a} \sim \mathrm{n}$ は本文参照，0はこま型砂岩のあった 洞窟大口

b. $160 \mathrm{~m} \times 3 \mathrm{~m}$ ，有孔虫款を主とするビーチロッ ク. 走向 $\mathrm{N} 40^{\circ} \mathrm{W}$, 傾斜海側へ $5 \sim 10^{\circ}$. 完全に潮間 帯に位し，低潮時には底部まで離水する．前崖は比 高 $50 \mathrm{~cm}$, 礁湖堆積物の上に落ちる. 背面は 3 枚ほ どあり，各 $20 \sim 30 \mathrm{~cm} ，$ ほぼ平滑であるが，大きな 転石をのせた部分がある, 陸側への最後の崖面は 50 〜 100cm の急斜面をなし，ときに $1 \mathrm{~m}$ ぼのオーバ 一ハングを突出させる. 幅が狭く，いちじるしく直 線状に走る点でもっとも典型的なビーチロックの一 つである。明かに c 以下のビーチロック群より外側 にあり，その間に幅 $3 \mathrm{~m}$ ほどの水面をはさむ．先報 に抢いて報告した名瀬市長浜のものと同様，帯状に 分帯されたビーチロックの実例である.

c. $6 \mathrm{~m} \times 3 \mathrm{~m}$. 成分や形態はbに類似し, 高潮に は下端のみ沈水する。

d. ほぼ c の延長に相当する. $30 \mathrm{~m} \times 4 \mathrm{~m}$. かなり 緻密で，最後の稜線の屈曲がいちじるしい，東端約 $5 \mathrm{~m}$ は大きく転可しており，背面が陸側へ $10^{\circ}$ 傾き， 走向 $\mathrm{N} 80^{\circ} \mathrm{W}$ を示す. 淡褐色.

e. $25 \mathrm{~m} \times 4 \mathrm{~m}$. 外観は濃褐色. 新鮮な断面は黄 褐色で，有孔虫殼を主とする. 走向 $\mathrm{N} 40 \sim 60^{\circ} \mathrm{W}$, 傾斜は海側へ $5 \sim 10^{\circ}$.

f. $25 \mathrm{~m} \times 4 \mathrm{~m}$. 外観は濃褐色. 前崖は $\mathrm{b}$ に並び陸

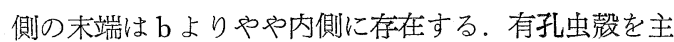
とする。

g. 台風 15 号 (Jean, 1965 年 8 月 4 日, 沖永良部 島西方を通過, 8 月 3 日午前 9 時よりの 48 時間に同 
島測候所では雨量 $475 \mathrm{~mm}$ を記録した. ) の直前には このビーチロックは砂浜には露出していなかったが， 台風直後には長さ $50 \mathrm{~m}$, 幅 $3 \sim 5 \mathrm{~m}$ にわたって露出 した．淡黄色．有孔虫殼を主とし，貝，さんごなど の破片を多く含む．かなり緻密．走向 $\mathrm{N} 40^{\circ} \mathrm{W}$. 稜 線はかなり座曲しているが，背面は比較的平滑であ る. i の一部に連続するものと思われる。

h. 佐久田俣川，台風前に厚い砂層に打おわれ， 川筋は見えなかったが，洪水時には幅 4〜 5m の河流 を作り，河口部に径 $100 \mathrm{~m}$ ほどの半円形のデルタを 形成した. ビーチロクの一部はこのデルタに打打わ れたが，また川底に新たに露出したビーチロックも ある。

i. $150 \mathrm{~m} \times 50 \mathrm{~m}$. 幅の点では筆者のこれまで調査 したビーチロックの中，第 1 級に属する，巻尺とハ ンドレベルを用いて簡易測量を行ない第 4 図を得た。 これについては後に説明を加えたい。

j. 中央クリフのベンチの部分. ビーチロックと くらべて次の諸点で明かに区別される.

(イ)さんご石灰岩より成る.

(口) 微ケスタ状を呈さない.すなわち崖面をもた ず，一続きの面をなす。
（汀線より崖下までしだいに急となる横断面を 示す，傾斜は下部で $5^{\circ}$ ，崖下で約 $12^{\circ}$.

（無数の小凹凸があり，また穴と穴を分つ稜角 が鋭い。

(林)汀線が不規則である。

いわゆる琉球石灰岩には多くの異相が知られ，そ のあるものについては構成物質の点からのみでは， ビーチロックと区別のつかない部分も存在するよう である。もしそのような部分が偶然, 現汀線と平行 する走向を有し，しかも海側に向って緩傾斜を示す 場合には，それを刻んでできる波食台地はビーチロ ックときわめてょく似た地形を現出する可能性があ る。しかしこのような偶然の重なる確率は少いので 筆者の調査範囲では德之島東海岸にやや㫐問の地形 があるほか，この点に関して混乱をきたしているも のはない.

k. 中央クリフ以東に展開するビーチロック， i と同様な方法によって測定し，図化したのが第 3 図 である、ここでは汀線に斜交する稜線がいちじるし いので，とくに面の走向を多く計測して記入した。 対象が背面のみなら比較的規則正しい数值が得られ るはずであるが，突出礫の影響や剝離現象，溶食作

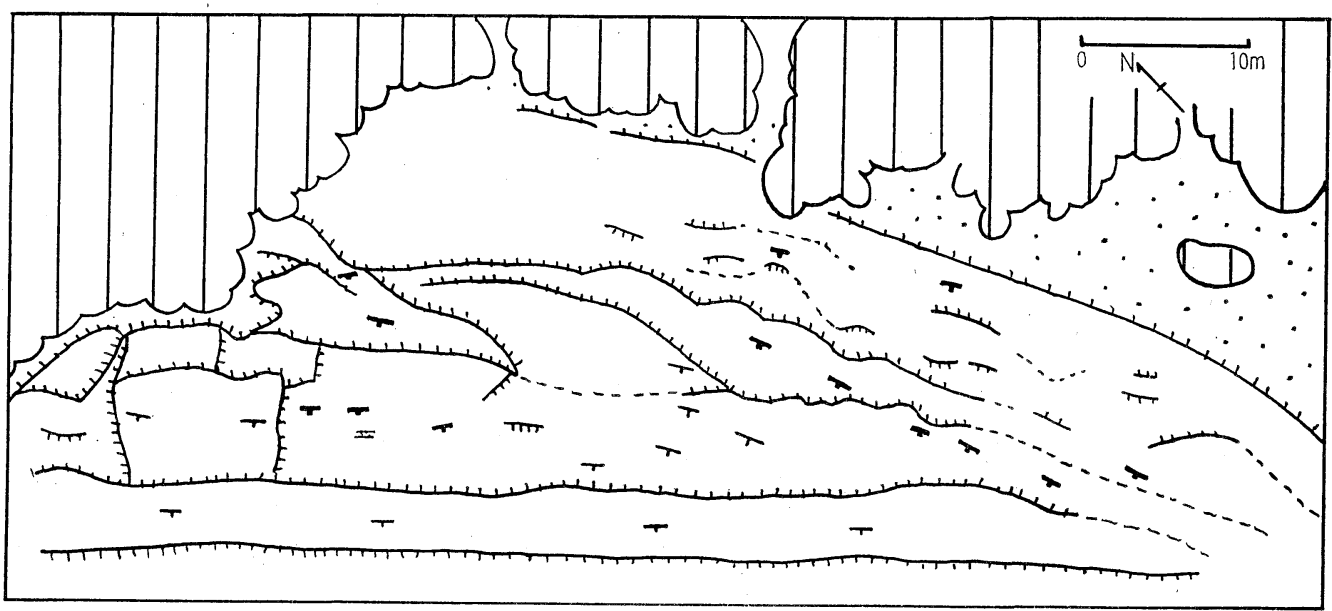

第 3 図 大津勘東浜のビーチロックの走向 


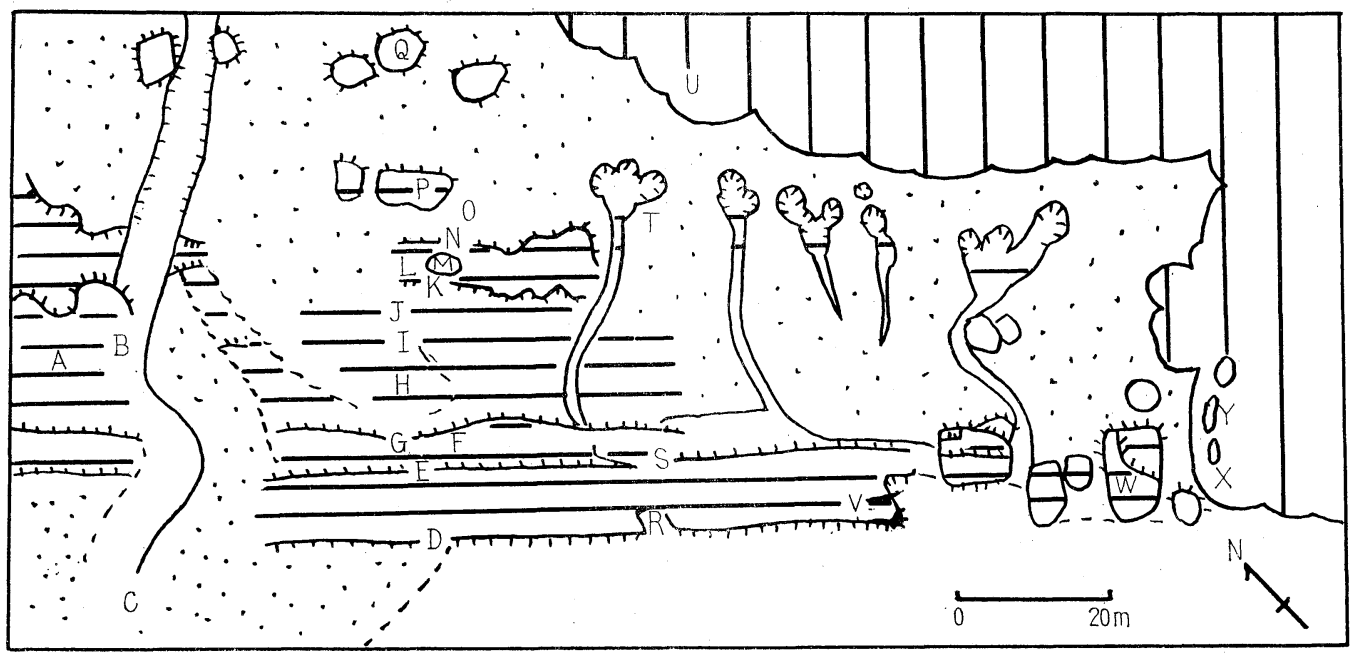

第 4 図 大津勘西浜のビーチロック 記号は本文参照

用などによって，原地形が大きな変化を受けている ので，局部的な走向傾斜の変化が大きい，約 $50 \mathrm{~cm}$ $\times 30 \mathrm{~cm}$ の板划れを背面と思われる面上にのせ，ク リノメーターで走向を測ったが，それらのうち，突 発的変異を見せる数值を除いて第 3 図に記入した。 走向の斜交する原因については汀線の変化のほか, 地下水流の変化も考虑に入れなければならない，侵 蝕程度については, 陸上露出時間の長いビーチロッ クの陸側部分の方が，海側部分にくらべて侵蝕の進 むのが当然であるから，単に侵蝕の進み方のみから ビーチロック生成の新旧を判定するのは危険である.

1 と药いずれも隆起さんご礁を刻むべンチである が，上にビーチロックをうすくのせている.ビーチ ロックの上には砂礫を欠く.

n. 隆起さんご礁. 汀線より急にそびえ, ベンチ を欠く．海抜 $5 \mathrm{~m}$ ほどの小平坦面はいちじるしい海 岸ラピエをなし，その間に潮吹き穴などが見られる。

以下大津勘西浜のビーチロック（第 4 図）につい て説明する。

A. 川の右岸へのビーチロックの延長部. 洪水 前には見えていなかった。

B. 佐久田俣川. 洪水後の川筋はやや蛇行してい
るが，ビーチロックの崖面の影響をうけている模様 である、川底には滝つぼや毆穴も見られた。

C. 河口部のデルタ. 頂置層がビーチロックの 一部をおおい，その前方に前置層がちようどビーチ ロックの前崖をおおうように発達し, 底置層は礁湖 底にひろがっていた。

D. 前崖. 比高 $50 \mathrm{~cm}$ の急崖 $\left(50^{\circ}\right.$ 以上, 時に才 一バーハング）をなし, 礁湖さんご礁の上に落ちる. 礁湖さんご礁は汀線に直角方向にのびる凹地をむつ ため，潮が引いてゆくにつれ鋸㐘状の汀線を現し， 直線状に走るビーチロックの前崖とはいちじるしい 対照を示す. 前崖加陸側に向って約 $20 \mathrm{~cm}$ の幅に わたって，背面はほぼ走向 $\mathrm{N} 40^{\circ} \mathrm{W}$ ，（現汀線に平 行), 傾斜海側 $5 \sim 10^{\circ}$, 厚さ $20 \sim 50 \mathrm{~cm}$ 前後の層 が数枚重った典型的ビーチロック形態を示す．とく に最上層の背面は長さ $100 \mathrm{~m}$ ，幅 $15 \mathrm{~m}$ にわたり，ほ とんど全く侵蝕をうけていない平滑な斜面を現して いる，岩石は有孔虫款を主とし，緻密である，海側 の $2 \mathrm{~m}$ ほどは藻類が付着しきわめて滑りやすい。こ の面は筆者のこれまで見たビーチロックのうち最も 大きな平滑斜面を形成している．前崖付近には汀線 方向の亀裂が多いが，これは不安定なオーバーハン 
グ部分にかかる水圧の急激な変化に基づくものであ ろう。平滑面の内側部分は小凹地をなし，汀線方向 に長い不規則な浅いくぼみが連続している，比高の きわめて小さい崖面が平滑面の部分と浅い凹地の部 分の間に存在するはずだが，現地でも見きわめがた いほど緩やかなので，DE間を一括して第 1 背面と しておく.

E. 崖面. 陸側へ約 $50^{\circ}$ 傾斜し, 比高 $15 \mathrm{~cm}$. 第 1 背面のいちじるしい平坦性と対応し，この稜線はほ とんど直線的に走る.

F. 第 2 背面. 汀線方向に長い長円形の浅いく ぼみが多い. 海側へ $5^{\circ}$ 傾斜. 構成物質は第 1 背面と 同じである。

G. 崖面. Eによく似ている.

H. 第 3 背面. さんご破片を多く含み，引す桃色， 緻密.

I. Hにつづく面でほぼ水平.

J. HI に続く面で陸側にわずかに傾く．HIJ は 一見たわみのように見えるが，側面の観察によれば， IJ の上部が侵蝕または剥離をうけたあと，うすく （約 $3 \mathrm{~cm} ）$ 上面に新しい被覆層を生じたように思わ れる。な抢このあたりのビーチロックは一応原地形 と考えられる形態を生じたあと，何回も侵蝕，剝離 による欠損と，充填，被覆などによる付加とを繰返 してきた可能性がある．構成物質と色彩とをいちじ るしく異にする 2 層が見脚け上互層しているように 見える部分もあるが，後述するように一方が他方に 後から付着した関係になっていることが多い．

K. 逆崖. EGなどの崖面が直線状に走るのに対 し，いちじるしく屈曲する，崖面が理論上，ビーチ ロックの原地形の一部として必然的に存在するのに 対し，逆崖はその後の亀裂をもとに，波食や溶食作 用などによって発達するはずである，一般に崖面に くらべて比高も一定せず，走り方も不規則なのは， このような成因の違いを考えれば当然であろう。
L. Kによって J と境される。陸側へ $5^{\circ}$ 傾く. 走向 $\mathrm{N} 80^{\circ} \mathrm{W}$ といちじるしく乱れ，背面ではないこ とを示す。

M. 小崖によって取り囲まれる残り面（?）. 此 高 $30 \mathrm{~cm}$. 走向 $\mathrm{N} 50^{\circ} \mathrm{W}$ で背面である可能性もある が，海側へ $15^{\circ}$ 傾斜している点が少し大きすぎる。 大きな転石が偶然相似の走向に乗ったとも考えられ る。質的な差は L と $\mathrm{M}$ の間には認められない。

N. 一部はかなり屈曲する崖面をなし，一部は 砂に理まっている。このあたりは波食，溶食のほか 風食作用当うけている。

O. 砂が打おっている部分. 掘ればすぐビーチ ロックの上面にあたる

P. 砂から現れているビーチロックの最後の部 分. 屈曲の多い崖面をもって終る. DP 間は約 $50 \mathrm{~m}$ である。

Q. ビーチロックの転石. 厚さ $40 \mathrm{~cm}$, 長さ $2 \mathrm{~m}$, 幅 $2 \mathrm{~m}$ 。なおこの種の転石は佐久田俣川に沿って河

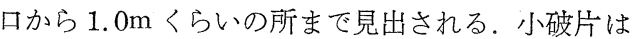
浜のいたる所に転がっている。さんご石灰岩の転石 多多小.

R. 汀線方向执よびこれに直交する亀裂によっ て落盤が扎こり，小さい入り込みをなす。中に落ち こんだビーチロックがあるが，その一つは走向N80 $\mathrm{E}^{\circ}$ ，傾斜海側へ $15^{\circ}$ を示す.

S. 汀線に小さい角度で交わる二つの電裂線に よって生じたくさび状の凹地.

T. 洪水後の湧水地点. 馬蹄形をなし, 径 $2 \sim 3 \mathrm{~m}$. 約 $70^{\circ}$ の崖をなす．底にえぐり出されたビーチロッ クが見える、構成物質は D-Hの部分と大差ないが， 純白できわめて緻密であり，ハンマーによる手ごた えが最も堅硬である，上下両面ともほとんど平滑で ある. Dすなわちビーチロックの海側末端との比高 は約 $2 \mathrm{~m}$ ．またこのビーチロックを埋めている砂の 厚さは約 $1 \mathrm{~m}$ である。ビーチロックの厚さは $40 \mathrm{~cm}$, 
走向 $\mathrm{N} 30^{\circ} \mathrm{E}$ ，傾斜海側へ $5^{\circ}$ 。

なおこのような湧出地点が数か所あり，新鮮なビ 一チロックが存在することは同様であるが，あるも のはビーチロックの下を早い速度で水が流れ砂を押 し流したために，ビーチロックが橋のようになり， その一部が落盤しかかっているのも見かけられた。 このような理由で，新鮮なビーチロックであっても 背面が連続していないこともあり得る.

U. 隆起さんご礁の崖の前面に砂が吹き寄せら れて作った砂丘. ここでは dune rock 化したものは 見当らなかった。背後に隆起さんご礁があり, 高度 10mほどの小台地を形成している.

V.このあたりから龟裂がいちじるしく多くな る.VW間の汀線の不連続はこれに起因する.

W. 下部は明らかにさんご石灰岩。その上に数 $\mathrm{cm}$ の厚さのビーチロックが付着している.

X. WX間に小入江があり，これが隆起さんご 礁を刻むべンチと，ビーチロックとの境界となって いる.

Y. ここにはきわめて特殊な現象が見られる.す なわちさんご石灰岩を打打って乳白色, 縞状の結晶 質石灰岩が存在する。これは風化するといちじるし い黒白の縞模様を呈するので，岩石の面上に墨流し 模様が展開する。一つにつき長さ $2 \mathrm{~m}$, 幅 $2 \mathrm{~m}$ ，厚 さ $15 \mathrm{~cm}$ ほどで，陸側から海側に向ってほぼ直線状 に四つほど存在する．付近のさんご石灰岩のくぼみ にもわずかに付着している，この成因は明かでない が，きわめて狭い幅に限られ，しかもほぼ一様に並 んでいるので，ある種の涌水と結びつく現象と考え られる。

以上，大津勘の浜に見られるいくつかのビーチロ
ック群について述べたが，汀線と背面の走向の関係 および侵蝕程度よりすると $\mathrm{k}$ (第 2 図) がもつとも 古く，佐久田俣川右岸のグループがこれにつぎ，同 左岸のものが比較的新しいようである。これは豪雨 後の地下水の湧出が佐久田俣川左岸のみに限られて いたのと関係があるであろう．現在生成中と考えら れるもっとも新鮮なビーチロックはこの佐久田俣川 左岸の砂丘裾にのみ見られるのである．しかし時代 決定に十分な出土品のない現在，以上の考察はまだ ほんの推論の域をでない。

\section{2. （実例 2 ） 白浜，沖永良部島.}

知名港西方 $1 \mathrm{~km}$, 現在築港工事中である. 海岸付 近には
A. 基盤の輝緑凝灰岩
B. その上に不整合にのる琉球石灰岩（二枚貝， 巻貝を多量に含み，濃い肉色を呈するさんご石灰 喆)

C. 有孔虫款を主とするビーチロック の 3 種類の地層が出現する.

$\mathrm{A}$ に関しては問題ないとしても， $\mathrm{B}$ と Cの上下関 係については見誤りやすい場合がある，幸いこの浜 においてはBとCの岩相がいちじるしく異っている ので，両者の結合関係についていくつかの実態をつ かむことができた．第 5 図の 1 はもっともふつうの 上下関係である。2 2 Bの一部がくぼみを作り，C が付着したもの，それが極端になると 3 のようにB のオーバーハングがいちじるしくなり，BとCとが 互層しているように見える部分を生じる。しかし 4 のように全く同形なBの空所に未凝固砂礫層が入り こんでいる場合もあるので， 3 のような解釈を下す

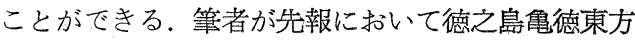
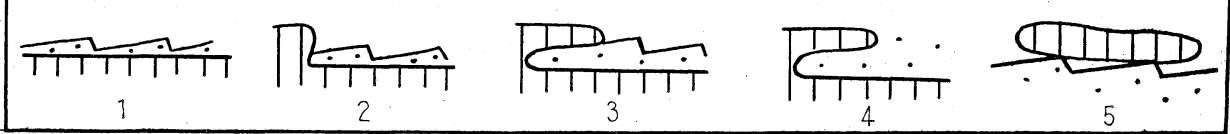

第 5 図さんご石灰岩（縦線）とビーチロック（点）の関係の 4 点は未凝固砂礫 
海岸のビーチロックとしたものは, その後の精査に よって琉球石灰岩を切るベンチ，またはその後の礁 湖堆積物層と解釈すべき部分が多いことがわかった が，その一部には明らかにビーチロックがあり，こ こにあげたのような状態を呈している．5はBの扁

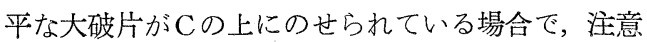
深く観察すれば識別に困難ではない。

結局この浜では，基盤および隆起さんご礁を刻む ベンチが成立したあと若干の隆起があり，ベンチの 部分が寸断されると同時に，ベンチを形成している さんご石灰岩の下部に溶食がすすみ，オーバーハン グを生じ，その空所に砂樂が堆積してビーチロック 化した（もちろん，オーバーハングの下ばかりでな く，砂浜一带がビーチロック化した）むのと考えら れる。

なおこの一種の洞窟的部分における堆積物のビー チロック化3)がさらに大規模に行われた可能性もあ る。知名港付近，あるいは同島喜美留付近に見られ るような直径 $1 \mathrm{~m}$ 以上におよぶ大䃯を含む厚さ数 $\mathrm{m}$ の礫岩層を，かって海岸近くに存在した洞窟中に堆 積した礫層が，鐘乳石的な石灰沈着によって膠結し たと解釈できる部分もあるようである。

\section{3.（実例 3 ） アヤマル岬，奄美大島笠利半島}

岬は標高 $47 \mathrm{~m}$, 砂岩・頁岩の互層する小丘で, そ の背後に国頭礫岩より成る 20〜30m の台地がある， 岬の北岸はほぼ東西に走り，海岸線に平行して砂丘 がある．砂丘と台地の間には低地があり，水田とな っている。低地の排水河川は砂丘を切っているが, 平常は水流を欠き，水は砂丘下部を浸透して海に達 しているものと思われる. 岬から涸れ川まで約 $500 \mathrm{~m}$ の間に三つのビーチロックがある。その外側はいわ ゆる礁湖で，高潮に没するが低潮には鞉を需らさず 最外縁まで達することができる．外縁にリーフがあ
り，礁湖面より約 $50 \mathrm{~cm}$ 高い。礁湖面には上面の平 らな大岩塊（高さ $2 \sim 3 \mathrm{~m}$ ，直径 $5 \sim 10 \mathrm{~m}$ ) が散在し ている. negro's head である. いずれもさんご石灰 岩より成り，暴浪時にさんご礁の一部が破壊され， 打ち上げられたものであろう。リーフの外緑は急に 深くなるが，また外縁に直交する多くの小溝がリ一 フを刻んでいる。この小溝は礁湖部分に達していな い. 礁湖の一部にはアャマル岬と同じ砂岩互層より 成る波食面も存在するが，これらは礁湖面よりやや 高い.

三つのビーチロックのうち注目されるのは中央の もので, $100 \mathrm{~m} \times 20 \mathrm{~m}$ ，三つのうち最大である．横 断面について上部よりいえば,

a. 砂丘,ソテツが生育する.

b. dune rock 化した部分. 厚さ $2 \mathrm{~m}$. 数 $\mathrm{mm}$ の葉 理の集合．砂粒は最大径 $2 \mathrm{~mm}$ 前後. おゔただしい 貝破片と有孔虫殼とを含んでいる．

c. 固結度の弱いビーチロック，石灰質礫岩であ る点は次のものと同じであるが，みかけ上凹凹が少 く，ハンマーの手ごたえも dune rockに似ている. 海側に緩傾斜する。

d. 微ケスタ状を示す，いずれも縱横の溝と円形 の凹地（直径 $80 \sim 100 \mathrm{~cm}$ のものが最も多い）によ。 て侵蝕されつつある. 陸測部分は凹地深さ $10 \mathrm{~cm}$ ほ どで浅く，底には砂がたまっている。前崖に近い部 分では穴は急に深くなり，中には下までつきぬけて いるものもある。

e. 比高 $1 \mathrm{~m}$ におよふ前崖。一部はオーバーハン グをなす。唓裂が多く，不安定な地带をなす。

\section{4.（実例 4） 長目の浜，瞄島}

上㽀島の北岸には礫州の発達がいちじるしく，海 眔池，貝池，鍬崎池，須口池の 4 潟湖をふちどり， また遠見山を陸繫している．礫は北面より南東に向

3）ビーチロック化というより単に石灰分による膠着といっておく方がよいかもしれない。ビーチロックの 成因に関する学説の混乱はビーチロックの定義のあいまいさから来ている点も多分にあるようである. 
って大きさを減じ，転流の方向を物語っている，ビ 一チロックの露出するのは海鼠池の外縁をなす長目 の浜の中央部以西のみであるが，他の部分にも厚い 礫層の下にかくれている可能性が大きい，潟湖は礫 州が完全に透水性であるためほとんど海水に近い成 分をもち，海よりややおくれて干満するが，山地端 に湧水地点があるため干潮時にはやや淡水による希 薄化をうける。

長目の浜のビーチロックは砂を全く含んでいない 点と，長さ $1 \mathrm{~km}$ にもわたる長大なものである点に よって注目される，海水面との関係からいうと，や や下位に偏したビーチロックの代表である．大潮の 干潮時のみに現れ，その際孔下端はなお海中にあっ て露出しない。だだ筆者の 2 回の調査時がいずれも 低気圧通過後の荒天であったため，平常より水位が 高かった抢それがある。

下㬝島小牟田の海岸にも小規模ながら類似のビー チロックが存在する。背後に小鼬湖があり, 海水が 出入する点も同様である.

\section{5.（実例 5） 赤崎, 名瀬湾西北}

名瀬湾をかこむ海岸にはビーチロックが多い。こ のうち, 東岸の佐大熊, 西岸の長浜のものは先報の ごとくいずれも微ケスタ状を示す典型的なものであ るが，長浜から北に水浜の典型的ビーチロックを経 て，赤崎付近にいたるとかなり型の変ったビーチロ ックが出現する。ビーチロックと一括してよいかど ろか疑問であり，単純に地下水説のみでは説明でき ない点が多い。これは要約していえば先報において 被覆型として分類したものであるが，長浜付近の八 ッチ状の存在状態から北に向ってしだいに分布割合 を增加し，赤崎付近では崖下から海面まですべての ビーチ物質が完全に膠結した状態となる。また明か に現水位より $2 \sim 3 \mathrm{~m}$ 高位のものも存在するが，これ は実例 2 の末尾の部分でふれた知名, 喜美留のもの によく似た状態である。
古仁屋港の対岸にある金グリ岬（加計呂麻島）に も赤崎型のビーチロックが存在する. 大島海陕のか なり内部に大ったところであるにもかかわらずこの 付近はいわゆる古生層を切るかなり幅の広い波食台 地が生成している．被覆型のビーチロックは高位の ものと，ふつう水位のものとに分ける必要があろう。 後者は古いビーチロックが波食をうけて一種のベン チになったものではなかろうか．赤崎のもの，金グ リ岬のもの，いずれも礫の突出部が切られている点 から考えて，かなり波食作用をうけていると考えら れる。これに対して高位にある被覆型ビーチロック は䃯が划られていない。

\section{6.（実例 6） 金浜，鹿児島湾東岸}

佐多岬付近から始まって大隅半島には諸所にビー チロックが見られる。ここでは鹿屋市高須港の北 $1.5 \mathrm{~km}$ の金浜のものを例にあげよう，背後は熔結凝 灰岩, 降下軽石層, シラス層の丘陵で, 金浜の南北 を限る鼻，中央部の小島はいずれも熔結凝灰岩より 成っている. 浜の長さ約 $400 \mathrm{~m}$ ，中央よりやや南よ りに長さ $100 \mathrm{~m}$, 幅 $30 \mathrm{~m}$ 前後のビーチロックが発達 する (第 6 図).

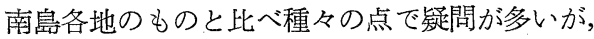
海岸付近に見られる現生胗結物層であることはまち がいない. 2,000B.P. と推定される弥生式土器を包 含している点，現棲のものが甚だ稀少であるにもか かわらず昔大発生を見たといわれ，鹿児島湾の海底 に多量に堆積しているといわれるモクハチアオイ Lunulicardia retusa の款をきわめて多量に含んで いる点から見て，比較的近い過去のある時代に膠結 作用がすすんだことは確実である。

南島のものとくらべると，

a. 微ケスタがはっきりしない. 金浜の一部では 含貝礫層の部分に微ケスタが現れるが，南島のもの に比してせせこましい感じである，他の部分では崖 面より逆崖の方がいちじるしい. 


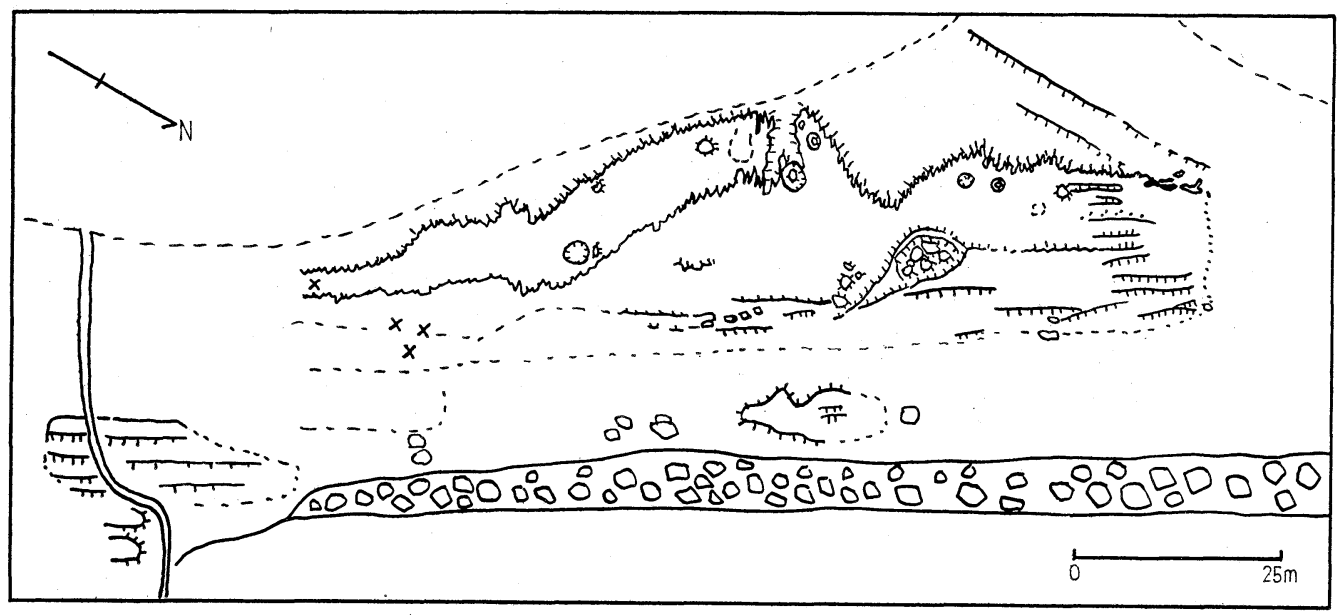

第 6 図 鹿屋市金浜のビーチロック $\times$ は土器出土地点

b. 膠結物の上下関係が連続的でなく, 含貝礫層 の部分など，いかにもとってつけたような感じがす る。これは軽石をふくむ部分について，その軽石が 切れていることから考えて，一部に古いビーチロッ クがあって，これが波食をうけたのち，新しい含貝 礫層の部分が被覆したのではないかと想像させる. すなわち，南島よりはるかに北方に位し，ビーチロ ック生成の限界線近くに存在するこのあたりでは, 僅少の海況の変化によりビーチロックの生成がやみ, 波食期に入り，その後再び生成期に入った可能性が ある。

c. 含有石灰分がいちじるしく少い.これは膠結 物質を化学分析した上でないと断定できないが，南 島のビーチロックが希塩酸によっていちじるしく発 泡するのに対し，金浜のものは発泡が弱いか，或は 全く発泡しない，したがって硬化の原因が炭酸石灰 の沈着によるもの以外のものが含まれれている可能 性がある. しかし坂元から荒平北方にいたる 6 ヶ所 のビーチロック（またはその類似地形）の出現地が， いちじるしく貝殼の多い浜に限定されているのは興 味深い事実である.
国鉄荒平駅北方 $500 \mathrm{~m}$ の海岸にもほとんど相似た 含貝磁岩層を主とするビーチロックが出現する． $25 \times 15 \mathrm{~m}$ くらいの小規模のものであるが，その南端 近いところ，上面とは約 $50 \mathrm{~cm}$ の比高をなす背面 （?）に繩文式土器が付着していた．專門家 ${ }^{4)}$ の鑑 定によればおそらく繩文前期（または早期）のもの であるという．ビーチロック生成期の鍵をにぎるも のとして注目される。

\section{III. 類ビーチロック地形}

砂丘その他の海岸堆積物が石灰分によって膠結さ れている地形をこの項に一括しょう.

1. dune rock. 文字通り砂丘岩と訳すべきであ ろうか。あるいはジューンロックと書く方がよいか。 砂丘の一部が硬化しているもので，薄層または固結 度の弱いものは各地に見出されるが，種子島以南で は厚さ $1 \mathrm{~m}$ 以上に拈よぶものがあり，ハンマーで吒 いて子容易に割れない石灰質砂岩を形成することが 多い，古期砂丘はもとより，現生砂丘にも多く存在 する．砂丘表面に硬い被膜をつくる場合もあるが， 表層より 30〜 40cm 下にできていることがもっとも

4）河口貞徳氏，鹿児島大学講師，鹿児島県文化財專門委員 
多い，固結度に強弱があるため，横断面が不規則な 凸凹を作ることが多い，砂丘堆積物が固結したので あるから，ビーチロックにくらべはるかに細粒より 成り，分級がすすんでいる。

2. 湧泉膠結層．前記 15 号台風の直後に白浜の 砂丘の一部にきわめていちじるしい実例が見られた。 これは砂丘中腹に湧出する地下水が，湧出によって 圧力を減ずるため $\mathrm{CO}_{2}$ 溶解度を減じ，岸酸石灰を 沈潵することによって生じたものであろう．石灰華 段丘の一種であるが，隆起さんご礁の風化物である 赤褐色の粘土の混入も膠結物の生成にあずかってい る模様である。な打段丘地形に隣接して, 直径 $1.3 \mathrm{~m}$, 高さ $1.6 \mathrm{~m}$ ほどの釣鐘状の土柱があり, 中央部に直 径 $30 \mathrm{~cm}$ ，深さ $40 \mathrm{~cm}$ ほどの円筒形の孔があって，下 半分に粘土，上半分に砂がたまっていた。かっての 涌水地点と考えるのはやや無理で，かっての砂丘上 の植物の根中心に砂丘砂が固結し，固結しなかった 周辺の砂丘砂が移動したあとに取り残された地形と 一応考えておく，中央の孔が付近に生育しているソ テッの幹の大きさとよく似ていた。

3. こま (独楽) 型砂岩 (仮称). 前記大津路の 海岸近くの洞窟入口で見た実例。海岸の飛砂が洞窟 をふさいでいるが，鍾乳石をつたう点滴がこの砂層 を固結して，鍾乳石の直下にべいごまのような形の 砂岩を作っていた，上面は直径 $40 \mathrm{~cm}$ の円形で，中 心部に小さいくぼみをもっていた，厚さ数 $\mathrm{cm}$ で下 へ向って小さくなる円艋の集合体をなし，全体とし
ては高ざ $40 \mathrm{~cm}$ ほどの逆円錐形を示す．これは点滴 が砂の表面に当って四散するため，その水の抢よぶ 籁囲で膠結が起こり，下部へ浸透する水量に比例し て下部ほど断面積が小さくなるために，このような 形となるのであろう.

これらの類ビーチロック地形が主としてビーチロ ックの出現する海岸の背後に現れることに注目した い.ビーチロックの固結作用と関連があるからであ る。

〔付記〕脱稿後, 桑代勲氏の好意によって武永の 論文5)を読むことができた，地下水以外に種々の成 因があることは扔そらく武永の指摘のと抢りであろ うが，本稿に取り扱ったように地下水説で説明する ことのできるビーチロックが存在することもまた確 かなようである。ビーチロックの生成年代について は，奄美大島ではその下限はほとんど現代に連なる と思われるが，分布限界線の近くではある一定の時 代に限定されるであろう。そしてそれは抢そらく高 温期を示すりのと思われる。これに対して橘によっ て発見された五島の繩文式土器，筆者らによる鹿児 島湾東岸の繩文・弥生式の土器は一つの重要な資料 になるものと思われる。

末管ながら調查に当って至便をはかられた知名町・赤 地町長, 大屋忠雄, 神川盛藏, 測量に協力された上床洋一, 脇門幹雄，奥正弘，浜村はる，金泜のビーチロックを発 見された清和次の諸氏，および研究費の一部を恵与され た鹿児島大学援助会汇対して心からの謝意を表したい， (1965年 9 月 24 日受理)

5）武永健一郎（1965）：与論島における beachrock と lagoon. 地形研究 5 広島大学地形研究会 


\section{THE BEACH ROCK AND ITS ANALOGOUS LAND FORMS.}

\section{Seiji YONETANI}

This paper mainly reports three groups of beach rock found on the beach of Otsukan, the south-west corner of Okierabu Island. The oldest group is seen between Central and East Cliffs. The surface planes strike obliquely to the present coast line and have been strongly erode away. The intermediate beach rock group is situated on the right bank of the river. It consists of 6 beach rocks which lie parallel to each other and to the present coast line, and is chiefly composed of foraminifera, containing coral fragments, shells, sands and gravels. The last one, the largest, lies between the River Sakutamata (usually waterless) and Central Cliff. It is 100 meters long, 50 meters wide, and 1 meter thick. The most seaward part of this group has a quite smooth and slippery surface. The middle and landward parts have been eroded to some degree. Wind erosion is to be seen, too. After Tyhoon Jean, which attacked this island during the writer's stay there, i. e., 4 August 1965 , bringing heavy rains ( 475 millimeters in 48 hours), the river began to flow. On the one hand, it formed a delta at the mouth, and covered some parts of the beach rocks, and on the other, excavated some beach rocks in the beach sands. Springs gushed out also, and uncoverd fresh beach rocks under their bottoms. It is clear that beach rocks are being formed at present.

There are many other examples analogous to beach rock: such as dune rocks, hardened rocks around springs and bell-like and top-like sandstones. It is to be noticed that these landforms appear only behind the beaches which have true beach rocks. Perhaps the cementing process of beach materials be very similar to each other in these cases. 